\title{
Scientific System in Romania and Portugal. A Quantitative Approach
}

Calcedonia Enache ${ }^{1}$ and Pedro Ribeiro Mucharreira ${ }^{2}$

${ }^{1)}$ The Bucharest University of Economic Studies, Bucharest, Romania.

${ }^{2}$ Institute of Education, University of Lisbon, Lisbon, Portugal.

E-mail: calcedoniaenache@yahoo.com; E-mail: prmucharreira@ie.ulisboa.pt

\begin{abstract}
Please cite this paper as:
Enache, C. and Mucharreira, P.R., 2021. Scientific System in Romania and

Portugal. A Quantitative Approach. In: R. Pamfilie, V. Dinu, L. Tăchiciu,

D. Pleșea, C. Vasiliu eds. 2021. 7th BASIQ International Conference on New

Trends in Sustainable Business and Consumption. Foggia, Italy, 3-5 June

2021. Bucharest: ASE, pp. 889-896 DOI: 10.24818/BASIQ/2021/07/111
\end{abstract}

\begin{abstract}
This research aims to highlight the evolution of the Portuguese and Romanian scientific system in the recent decades. This article presents the process of expansion of higher education in both countries, particularly at the level of the scientific system, trying to understand how scientific research in Portugal and Romania has evolved, as well as to know the sectors that conduct this activity. In this article, the authors support their analysis using Portuguese and Romanian official statistics and from international organizations, some indicators that can clarify the volume and quality of scientific research in these two countries between 2007 to 2019, analyzing the expansion of scientific research in the post-Bologna context. The article will be finished with two unifactorial regression models analysis. The main results of the study point towards that, for the period 2007-2019, in the higher education sector, a $1 \%$ growth in R\&D expenditures leads, on average, to an increase in the number of researchers by $0.18 \%$ in Romania and $1.25 \%$ in Portugal. These results may help to formulate public policies conducive to improving the state of public higher education in Portugal and Romania, especially in the financing of postgraduate and scientific production.
\end{abstract}

\section{Keywords}

Higher Education, Scientific System, Public Policies, Research, Financing.

DOI: $10.24818 / B A S I Q / 2021 / 07 / 111$

\section{Introduction}

Education and science are key factors in promoting economic growth and human development. Higher levels of investment in these sectors significantly affects the quality of life and the possibility of constant development in both a country and the international community at large. Thus, science and qualified personnel are recognized in Europe as the decisive factor for the achievement of the internationalization objectives of the educational process, that is, to make European education more competitive, dynamic and capable of ensuring sustainable growth and the employment of the population. and social cohesion (Antunes, et al., 2018).

Several authors mention the importance of education and research for the growth and economic development of countries. The expenditure on this sector must be seen as an investment. These associated costs can be lessened, in the medium and long term, by taking into account reductions in grade retention and dropout rates, the rising educational level of the population, and the consequent increase in economic productivity and purchasing power, and the reinforcement of equity and social justice, among other aspects that may generally promote economic growth and development. Many studies demonstrate the positive relationship - a spillover effect - between educational levels and rising 
levels of economic growth and development, as well the social and economic development resulting from other indirect and non-monetary benefits, such as changes in fertility and birth rates, the encouragement of political participation and solidarity, as well as crime reduction. All of these represent incalculable positive externalities of education. (Mucharreira, et al., 2019a)

The development of the country as well as the improvement of the quality of the education provided requires the development of scientific research (Cerdeira, et al., 2020). For this reason, it is important to understand how scientific research in these two Member States of the European Union, Portugal and Romania, has evolved, as well as to know the sectors that conduct this activity.

The paper is structured as follows. After the introduction, a section describes the evolution of research and scientific production in Romania and Portugal. Section 3 presents the employed methodology and the data and the fourth the results of the model. Fifth section discusses the results, and the paper ends with the conclusions.

\section{Evolution of research and scientific production in Romania and Portugal}

In Portugal, in the last decades, the demand for higher education have increased continuously and significantly. The exception was in the period of economic and financial crisis that will have seen a reversal of the trend after 2015. Instead, Romania, during the economic crisis, went through a restructuring process, creating the conditions for further development on sustainable criteria (the number of employees in the public sector decreased, bank lending favored the tradable sector and the fiscal deficit eased). Thus, Table no. 1 shows the evolution of the total number of researchers in the period 2007-2019 as well as the sectors that develop it, both in Portugal and Romania.

Table no. 1. Number of researchers by sector in Romania and Portugal, 2007-2019

\begin{tabular}{|c|c|c|c|c|c|c|c|c|c|c|}
\hline \multirow{2}{*}{ Years } & \multicolumn{3}{|c|}{ Total } & \multicolumn{2}{c|}{$\begin{array}{c}\text { Business } \\
\text { enterprise sector }\end{array}$} & $\begin{array}{c}\text { Government } \\
\text { sector }\end{array}$ & \multicolumn{2}{c|}{$\begin{array}{c}\text { Higher education } \\
\text { sector }\end{array}$} & \multicolumn{2}{c|}{$\begin{array}{c}\text { Private non- } \\
\text { profit sector }\end{array}$} \\
\cline { 2 - 12 } & RO & PT & RO & PT & RO & PT & RO & PT & RO & PT \\
\hline 2007 & 30740 & 51443 & 7971 & 14457 & 6100 & 4607 & 16510 & 26703 & 159 & 5676 \\
\hline 2008 & 30864 & 75073 & 6623 & 18206 & 6541 & 4421 & 17579 & 46456 & 121 & 5990 \\
\hline 2009 & 30645 & 75206 & 6389 & 18126 & 6010 & 4425 & 18137 & 46717 & 109 & 5938 \\
\hline 2010 & 30707 & 80259 & 6182 & 19235 & 5831 & 5101 & 18540 & 48677 & 154 & 7246 \\
\hline 2011 & 25489 & 82354 & 4122 & 21191 & 6117 & 6059 & 15086 & 47017 & 164 & 8087 \\
\hline 2012 & 27838 & 81750 & 5451 & 21471 & 6664 & 4784 & 15569 & 48007 & 154 & 7488 \\
\hline 2013 & 27600 & 78290 & 5738 & 20621 & 6859 & 4101 & 14884 & 52827 & 119 & 741 \\
\hline 2014 & 27535 & 78736 & 5848 & 21646 & 6799 & 4510 & 14743 & 51924 & 145 & 656 \\
\hline 2015 & 27253 & 81005 & 4923 & 23498 & 7032 & 4620 & 15057 & 52325 & 241 & 562 \\
\hline 2016 & 27801 & 85780 & 5402 & 26332 & 7043 & 4614 & 15083 & 54248 & 273 & 586 \\
\hline 2017 & 27367 & 89659 & 4852 & 29410 & 6856 & 5327 & 15523 & 54307 & 136 & 615 \\
\hline 2018 & 27471 & 96123 & 5119 & 32411 & 7064 & 5501 & 15111 & 57532 & 177 & 679 \\
\hline 2019 & 27168 & 100823 & 4809 & 36855 & 7267 & 5839 & 14867 & 57416 & 225 & 713 \\
\hline
\end{tabular}

In 2019, by fields of science, the structure of researchers in the higher education sector in Romania illustrates the fact that most researchers worked in the field of engineering and technology $(37.6 \%$, down 10.8 percentage points against end 2007), followed by the fields of medical and health sciences ( $26.6 \%$, up 15.1 percentage points) and natural sciences (19.1\%, down 2.6 percentage points). On the other hand, in Portugal, most researchers worked in the field of social sciences $(24.6 \%$, up 2.7 percentage points), followed by the fields of natural sciences (21.6\%, down 6.3 percentage points) and engineering and technology (19.7\%, down 0.2 percentage points) (Table no. 2 ). 
Table no. 2. Number and percentage weight of researchers in the higher education sector by science fields in Romania and Portugal, 2007-2019

\begin{tabular}{|c|c|c|c|c|c|c|c|c|c|c|c|c|c|c|}
\hline \multirow{3}{*}{$\begin{array}{c}\text { Year } \\
\mathbf{s}\end{array}$} & \multirow{2}{*}{\multicolumn{2}{|c|}{ Total }} & \multicolumn{12}{|c|}{ Science Fields (\%) } \\
\hline & & & \multicolumn{2}{|c|}{$\begin{array}{l}\text { Natural } \\
\text { sciences }\end{array}$} & \multicolumn{2}{|c|}{$\begin{array}{l}\text { Engineerin } \\
\mathrm{g} \text { and } \\
\text { technology }\end{array}$} & \multicolumn{2}{|c|}{$\begin{array}{c}\text { Medical } \\
\text { and health } \\
\text { sciences }\end{array}$} & \multicolumn{2}{|c|}{$\begin{array}{c}\text { Agricultura } \\
\text { I sciences }\end{array}$} & \multicolumn{2}{|c|}{$\begin{array}{c}\text { Social } \\
\text { sciences }\end{array}$} & \multicolumn{2}{|c|}{$\begin{array}{c}\text { Humanitie } \\
\text { s }\end{array}$} \\
\hline & RO & PT & RO & PT & RO & PT & RO & PT & RO & PT & RO & PT & RO & PT \\
\hline 2007 & $\begin{array}{c}1651 \\
0\end{array}$ & $\begin{array}{c}2670 \\
3\end{array}$ & $\begin{array}{c}16 . \\
5\end{array}$ & $\begin{array}{c}27 . \\
9\end{array}$ & 48.4 & 19.9 & $\begin{array}{c}11 . \\
5\end{array}$ & $\begin{array}{c}10 . \\
3\end{array}$ & 3.8 & 4.2 & $\begin{array}{c}16 . \\
6\end{array}$ & $\begin{array}{c}21 . \\
9\end{array}$ & 3.2 & 15.8 \\
\hline 2008 & $\begin{array}{c}1757 \\
9 \\
\end{array}$ & $\begin{array}{c}4645 \\
6 \\
\end{array}$ & 5.2 & $\begin{array}{c}21 . \\
3\end{array}$ & 44.7 & 16.6 & $\begin{array}{c}15 . \\
1 \\
\end{array}$ & $\begin{array}{c}15 . \\
9 \\
\end{array}$ & 4.2 & 3.2 & $\begin{array}{c}24 . \\
1 \\
\end{array}$ & $\begin{array}{c}27 . \\
9 \\
\end{array}$ & 6.7 & 15.1 \\
\hline 2009 & $\begin{array}{c}1813 \\
7\end{array}$ & $\begin{array}{c}4671 \\
7\end{array}$ & 3.3 & $\begin{array}{c}22 . \\
9\end{array}$ & 45.5 & 17 & $\begin{array}{c}17 . \\
9 \\
\end{array}$ & $\begin{array}{c}14 . \\
8 \\
\end{array}$ & 4.2 & 2.6 & $\begin{array}{c}22 . \\
8 \\
\end{array}$ & $\begin{array}{c}26 . \\
3 \\
\end{array}$ & 6.3 & 16.4 \\
\hline 2010 & $\begin{array}{c}1854 \\
0 \\
\end{array}$ & $\begin{array}{c}4867 \\
7 \\
\end{array}$ & 2.1 & $\begin{array}{c}22 . \\
7\end{array}$ & 47 & 15.8 & $\begin{array}{c}12 . \\
3\end{array}$ & $\begin{array}{c}14 . \\
5 \\
\end{array}$ & 5.5 & 2.7 & $\begin{array}{c}25 . \\
8 \\
\end{array}$ & $\begin{array}{c}25 . \\
5\end{array}$ & 7.3 & 18.8 \\
\hline 2011 & $\begin{array}{c}1508 \\
6 \\
\end{array}$ & $\begin{array}{c}4701 \\
7 \\
\end{array}$ & $\begin{array}{c}18 . \\
8 \\
\end{array}$ & $\begin{array}{c}20 . \\
8 \\
\end{array}$ & 32.2 & 19.1 & $\begin{array}{c}16 . \\
1 \\
\end{array}$ & 14 & 3 & 3.9 & $\begin{array}{c}24 . \\
9 \\
\end{array}$ & $\begin{array}{c}25 . \\
6 \\
\end{array}$ & 5 & 16.6 \\
\hline 2012 & $\begin{array}{c}1556 \\
9 \\
\end{array}$ & $\begin{array}{c}4800 \\
7\end{array}$ & $\begin{array}{c}13 . \\
8\end{array}$ & $\begin{array}{c}20 . \\
5\end{array}$ & 42.4 & 17.6 & $\begin{array}{c}10 . \\
4 \\
\end{array}$ & $\begin{array}{c}15 . \\
2 \\
\end{array}$ & 3.6 & 2.9 & $\begin{array}{c}23 . \\
5 \\
\end{array}$ & $\begin{array}{c}26 . \\
1 \\
\end{array}$ & 6.3 & 17.7 \\
\hline 2013 & $\begin{array}{c}1488 \\
4 \\
\end{array}$ & $\begin{array}{c}5282 \\
7 \\
\end{array}$ & $\begin{array}{c}17 . \\
6 \\
\end{array}$ & $\begin{array}{c}21 . \\
5\end{array}$ & 40.1 & 19.2 & $\begin{array}{c}12 . \\
7\end{array}$ & $\begin{array}{c}14 . \\
8\end{array}$ & 10.1 & 2.6 & $\begin{array}{c}12 . \\
6 \\
\end{array}$ & $\begin{array}{c}24 . \\
2\end{array}$ & 6.9 & 17.7 \\
\hline 2014 & $\begin{array}{c}1474 \\
3 \\
\end{array}$ & $\begin{array}{c}5192 \\
4\end{array}$ & $\begin{array}{c}10 . \\
9\end{array}$ & $\begin{array}{c}21 . \\
2\end{array}$ & 40.7 & 19 & $\begin{array}{c}12 . \\
2 \\
\end{array}$ & $\begin{array}{c}15 . \\
1\end{array}$ & 10.5 & 2.6 & $\begin{array}{c}23 . \\
7\end{array}$ & 24 & 2 & 18.1 \\
\hline 2015 & $\begin{array}{c}1505 \\
7\end{array}$ & $\begin{array}{c}5232 \\
5\end{array}$ & $\begin{array}{c}18 . \\
5\end{array}$ & $\begin{array}{c}20 . \\
5\end{array}$ & 37 & 19 & $\begin{array}{c}12 . \\
4\end{array}$ & $\begin{array}{c}16 . \\
1\end{array}$ & 10.8 & 2.6 & $\begin{array}{c}18 . \\
9\end{array}$ & $\begin{array}{c}24 . \\
4\end{array}$ & 2.4 & 17.4 \\
\hline 2016 & $\begin{array}{c}1508 \\
3 \\
\end{array}$ & $\begin{array}{c}5424 \\
8 \\
\end{array}$ & 19 & $\begin{array}{c}20 . \\
6\end{array}$ & 43.4 & 18.8 & $\begin{array}{c}13 . \\
8 \\
\end{array}$ & 16 & 10.5 & 2.7 & $\begin{array}{c}11 . \\
1 \\
\end{array}$ & $\begin{array}{c}24 . \\
6 \\
\end{array}$ & 2.2 & 17.3 \\
\hline 2017 & $\begin{array}{c}1552 \\
3 \\
\end{array}$ & $\begin{array}{c}5430 \\
7 \\
\end{array}$ & $\begin{array}{c}20 . \\
6 \\
\end{array}$ & $\begin{array}{c}21 . \\
7\end{array}$ & 39.8 & 19.4 & $\begin{array}{c}18 . \\
3 \\
\end{array}$ & $\begin{array}{c}14 . \\
1 \\
\end{array}$ & 14.4 & 2.8 & 4.5 & $\begin{array}{c}24 . \\
5 \\
\end{array}$ & 2.4 & 17.5 \\
\hline 2018 & $\begin{array}{c}1511 \\
1\end{array}$ & $\begin{array}{c}5753 \\
2 \\
\end{array}$ & $\begin{array}{c}20 . \\
6\end{array}$ & $\begin{array}{c}21 \\
5\end{array}$ & 39.4 & 20 & $\begin{array}{c}22 . \\
9\end{array}$ & $\begin{array}{c}13 . \\
7\end{array}$ & 5.9 & 2.9 & 8.5 & $\begin{array}{c}24 . \\
3\end{array}$ & 2.7 & 17.6 \\
\hline 2019 & $\begin{array}{c}1486 \\
7\end{array}$ & $\begin{array}{c}5741 \\
6 \\
\end{array}$ & $\begin{array}{c}19 . \\
1 \\
\end{array}$ & $\begin{array}{c}21 . \\
6\end{array}$ & 37.6 & 19.7 & $\begin{array}{c}26 . \\
6\end{array}$ & $\begin{array}{c}13 . \\
9\end{array}$ & 7.4 & 2.8 & 6.8 & $\begin{array}{c}24 . \\
6\end{array}$ & 2.5 & 17.4 \\
\hline
\end{tabular}

Source: EUROSTAT; Romanian National Institute of Statistics; Own calculations

In Romania, the number of scientific and technical journal articles increased gradually from 5250 unit in 2007 to 10370 unit in 2010 and then shrank to 10055 unit in 2011. Further on, it went up to 10287 unit in 2012 and 10123 unit in 2013, oscillating around the value of 10577 unit during the next five years. At the same time, in Portugal, the number of scientific and technical journal articles had an average of 12303.2 unit in the period 2007-2018, the limits of the interval of variation being between 7654 unit and 14691 unit (Figure no. 1).

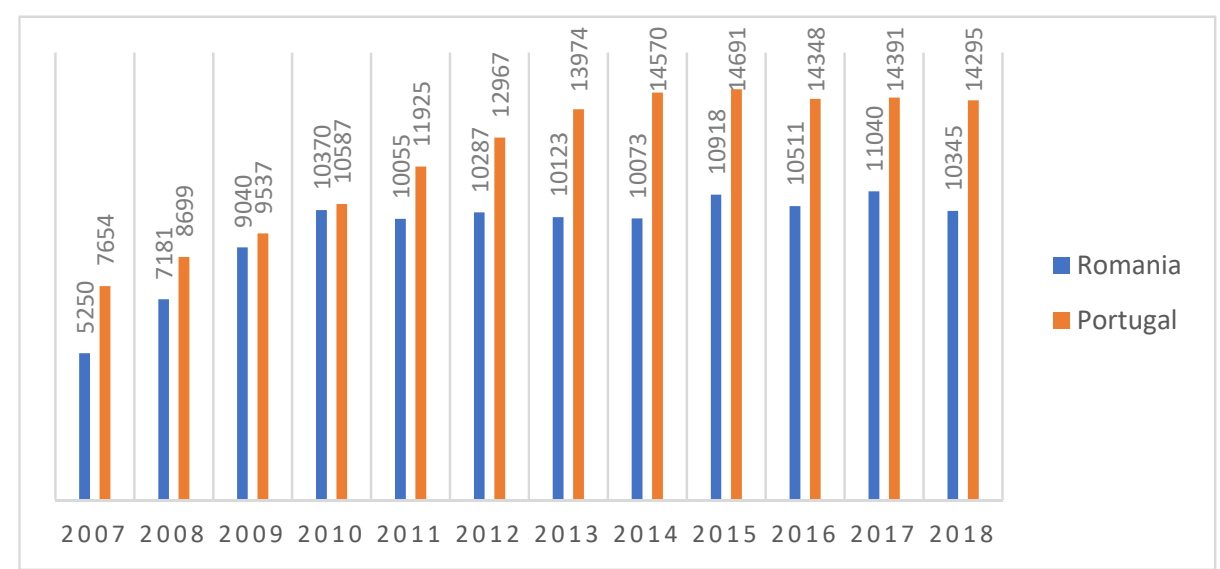

Figure no. 1. Scientific and technical journal articles in Romania and Portugal*, 2007-2018 Source: World Bank 
"Scientific and technical journal articles refer to the number of scientific and engineering articles published in the following fields: physics, biology, chemistry, mathematics, clinical medicine, biomedical research, engineering and technology, and earth and space sciences

According the SCImago Journal \& Country Rank portal, in 2019, Portugal and Romania ranked 11th and 17th out of 28 European Union (EU) countries after United Kingdom, Germany, Italy, France, Spain or Netherlands, but ahead of Hungary, Slovakia, Croatia, Slovenia or Bulgaria (Figure no. 2).

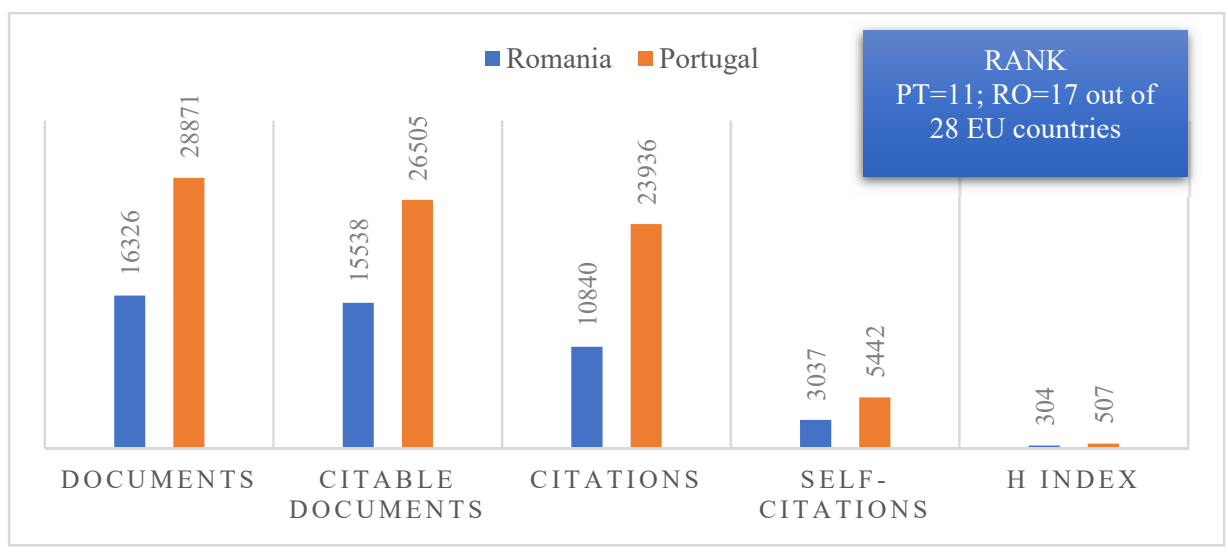

Figure no. 2. SCImago Journal \& EU 28 Country Rank in 2019

Source: SCImago Institutions Rankings

In 2019, total expenditure on research and development (R\&D) reached $0.48 \%$ of GDP (Gross Domestic Product) in Romania and 1.4\% of GDP in Portugal (Figure no. 3).

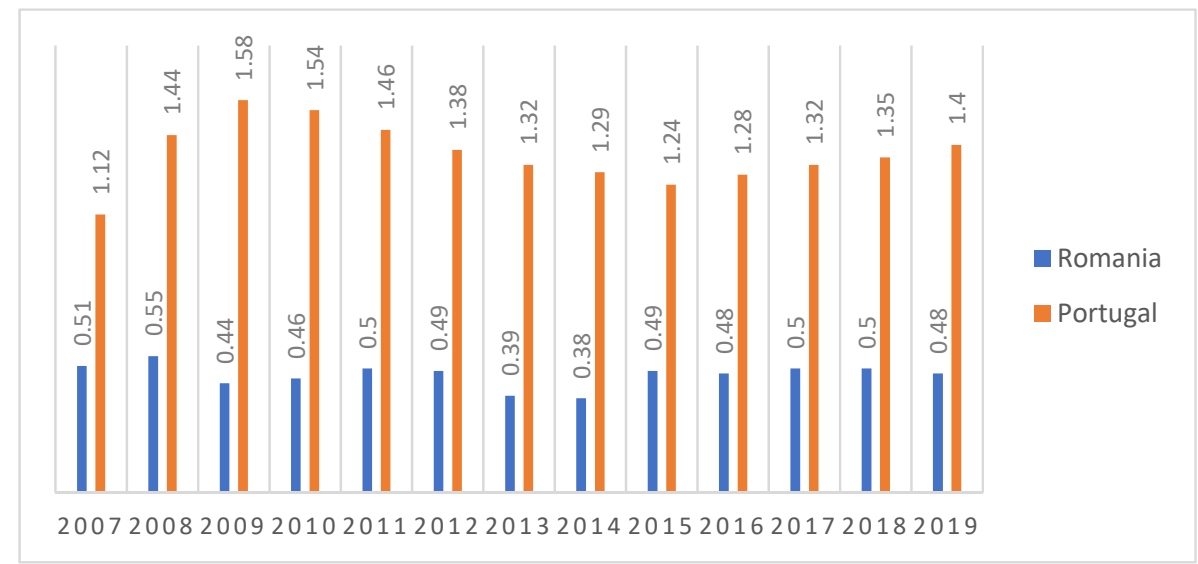

Figure no. 3. Research and development expenditure (\% of GDP)

in Romania and Portugal, 2007-2019

Source: EUROSTAT

According to Sokolov-Mladenović, et al. (2016), the GERD (Gross domestic expenditure on R\&D) as a percentage of GDP presents research and experimental development (R\&D), comprising creative work undertaken on a systematic basis in order to increase the stock of knowledge, including knowledge of man, culture and society and the use of this stock of knowledge to devise new applications.

\section{Material and method}

The present study examines the relationship between number of researchers in the higher education sector (RHES) and R\&D expenditure in the higher education sector (expressed in million purchasing 
power standards (PPS) at 2005 prices) (RDEE) in the economies of Romania and Portugal. In this regard, we estimated two unifactorial regression models, similar to those presented by Johnston (2014) and Jula et al. (2010). The data series have a yearly frequency, cover the time interval 2007-2019 and were provided by the EUROSTAT website. The series used were expressed in natural logarithms.

\section{Model estimation and results}

The two unifactorial regression models were estimated by the least-squares method using IBM SPSS Statistics 20. The results are presented in Table no. 3 and in Table no. 4.

Table no. 3. Romania -Model estimation results

\begin{tabular}{|c|c|c|c|c|c|}
\hline \multirow[t]{2}{*}{ Variable } & \multicolumn{2}{|c|}{$\begin{array}{r}\text { Unstandardized } \\
\text { Coefficients }\end{array}$} & \multirow{2}{*}{$\begin{array}{r}\begin{array}{r}\text { Standardized } \\
\text { Coefficients }\end{array} \\
\text { Beta }\end{array}$} & \multirow[t]{2}{*}{ t-Statistic } & \multirow[t]{2}{*}{ Sig. } \\
\hline & B & Std. Error & & & \\
\hline Constant & 3.792 & .128 & & 29.716 & .000 \\
\hline RDEE & .180 & .056 & .695 & 3.202 & .008 \\
\hline \multicolumn{2}{|l|}{$\mathrm{R}$} & .695 & F-statistic & & 10.253 \\
\hline \multicolumn{2}{|l|}{ R Square } & .482 & Sig.(F-statistic) & & .008 \\
\hline \multicolumn{2}{|c|}{ Adjusted R Square } & .435 & Breush-Pagan & & 1.8607 \\
\hline \multicolumn{2}{|c|}{ Std. Error of the Estimate } & .02648 & Sig.(Breush Pagan) & & .1725 \\
\hline \multirow{2}{*}{\multicolumn{2}{|c|}{ Durbin-Watson }} & 1.764 & Koenker & & 1.7839 \\
\hline & & & Sig.(Koenker) & & .1817 \\
\hline
\end{tabular}

Source: Research data processed by authors with statistical program SPSS

Table no. 4. Portugal -Model estimation results

\begin{tabular}{|c|c|c|c|c|c|}
\hline \multirow[t]{2}{*}{ Variable } & \multicolumn{2}{|c|}{$\begin{array}{r}\text { Unstandardized } \\
\text { Coefficients } \\
\end{array}$} & \multirow{2}{*}{$\begin{array}{r}\begin{array}{r}\text { Standardized } \\
\text { Coefficients }\end{array} \\
\text { Beta }\end{array}$} & \multirow[t]{2}{*}{ t-Statistic } & \multirow[t]{2}{*}{ Sig. } \\
\hline & B & Std. Error & & & \\
\hline Constant & .885 & .387 & & 2.285 & .043 \\
\hline RDEE & 1.250 & .127 & .947 & 9.827 & .000 \\
\hline \multirow{6}{*}{\multicolumn{2}{|c|}{$\begin{array}{l}\mathrm{R} \\
\mathrm{R} \text { Square } \\
\text { Adjusted R Square } \\
\text { Std. Error of the Estimate } \\
\text { Durbin-Watson }\end{array}$}} & .947 & \multicolumn{2}{|l|}{ F-statistic } & 96.577 \\
\hline & & .898 & \multicolumn{2}{|l|}{ Sig.(F-statistic) } & .000 \\
\hline & & .888 & \multicolumn{2}{|l|}{ Breush-Pagan } & .0229 \\
\hline & & .02842 & \multicolumn{2}{|l|}{ Sig.(Breush Pagan) } & .8797 \\
\hline & & 1.322 & \multicolumn{2}{|l|}{ Koenker } & .0188 \\
\hline & & & \multicolumn{2}{|l|}{ Sig.(Koenker) } & .8910 \\
\hline
\end{tabular}

Source: Research data processed by authors with statistical program SPSS

The estimation of the coefficients of the models leads to the following relationships:

$$
\begin{aligned}
& \text { Romania: } \text { RHES }_{\mathrm{t}}=3.792+0.18 \cdot \mathrm{RDEE}_{\mathrm{t}} \\
& \text { Portugal: } \mathrm{RHES}_{\mathrm{t}}=0.885+1.25 \cdot \mathrm{RDEE}_{\mathrm{t}}
\end{aligned}
$$

The 2 models are statistically valid, as long as the calculated values of the F-test are 10.253 (Significance F: 0.008) in the case of Romania and 96.577 (Significance F: 0.000) in the case of Portugal, explaining $48.2 \%$ and $89.8 \%$ respectively of the variation in the number of researchers in the higher education sector. The coefficients of the 2 models proved to be statistically significant after the Student's t-test was applied. The Durbin Watson test (see Durbin and Watson, 1950) was used in order to examine the autocorrelation of the residues. For a number of 13 observations, an exogenous variable and a result guarantee probability of 0.95 , the lower and upper critical values of the test are $\mathrm{d}_{\mathrm{L}}=1.01$ and $\mathrm{d}_{\mathrm{U}}=1.34$. We can state that the errors are not autocorrelated in the case of the estimated model for Romania (the value of DW is 1.764). Instead, we cannot say whether the errors are positively correlated in the case of the estimated model for Portugal (the value of DW is 1.322). The BreushPagan test Breusch (see Breusch and Pagan, 1979) and the Koenker test (see Koenker,1981) indicate that heteroskedasticity is not present in both estimated models. Besides, the results reflect that, for the period 2007-2019, in the higher education sector, a 1\% growth in R\&D expenditures leads, on average, to an increase in the number of researchers by $0.18 \%$ in Romania and $1.25 \%$ in Portugal. 


\section{Discussions}

The R\&D expenditure indicator is essential to make the transition to the knowledge-based economy that leads to increased competitiveness and well-being of the country. In the period 2007-2019, the R\&D in the higher education sector in terms of percentage of GDP fluctuated between $0.05 \%$ (PPS 186.094 million) and $0.16 \%$ (PPS 433.949 million) in Romania and between $0.33 \%$ (PPS 747.44 million) and $0.59 \%$ (PPS 1296.847 million) in Portugal. It should be mentioned that, on average, in the period 2007-2018, in Romania, out of total R\&D expenditure in the higher education sector, 59.63\% were destined for basic research, 30.62\% for applied research and $9.75 \%$ for experimental development. Instead, in Portugal, the expenditures for basic research and those for applied research represented $42.79 \%$, respectively $42.57 \%$ of total R\&D expenditure in the higher education sector. In the period 2007-2019, the number of requests for patent protection of an invention filed with the European Patent Office regardless of whether they are granted or not (PEPO) recorded a positive annual average dynamic in both Romania and Portugal (7.9\% and $11.8 \%$, the starting bases being 16 and, respectively, 71). If we correlate PEPO with GDP (expressed in million purchasing power standards), we find a positive relation with a Pearson coefficient of 0.85 for Romania and 0.93 for Portugal. These results were obtained given that in the performance sectors, the largest amounts of public funds were received by units in the government sector, followed by units in the higher education sector.

Romania records less favorable results in the area of innovation compared to Portugal, amid underfunding of the system, and the existence of an insufficient number of specialists employed in activities of research, development and innovation (Cheben, et al., 2020; Imbrișcă and Toma, 2020). It should be noted that the facilitation of the innovation by creating a stable legislative framework, by ensuring equal opportunities for access to resources, achieved through measures to reduce disparities between the eight development regions of the country and by applying qualitative criteria based on the results of prestigious international rankings in the financing of universities are important.

In Portugal there has been a gradual growth in the number of researchers and investment in the scientific system, however, underfunding is still a reality. Despite this positive development, the country remains quite far from the performance of the most developed countries in the world. In Portugal, higher education is the biggest employer of researchers, with its role growing over the last years. Conversely, the role of the State is decreasing intensely, at the same time that the role of research in the business world is growing. The growing participation of private companies in the employment of researchers, particularly in recent years, evidencing a change in the previous paradigm of higher participation of the State in scientific research (Cabrito, et al., 2019; Cerdeira, et al., 2019). In a country with huge public expenditure and which depends on the exterior such as Portugal, the funding issue is definitely a serious problem to be solved. And it is more serious when the investment is on goods or services, whose results are only perceived in the long-term. This takes place with services, such as security, health or education, which, in times of crisis, tend to be viewed as expenses and not as an investment, which generally results in their underfunding (Mucharreira, et al., 2019a; 2019b). In this context, it is not surprising that expenses with education are neglected when it is necessary to allocate the existing resources, particularly in times of depression and economic crisis. This is exactly what has been happening in Portugal with the provision of public services, including education (Mucharreira, et al. 2019a; 2019b).

\section{Conclusions}

In the present work it was evident the significant growth of the Romanian and Portuguese scientific systems.

Such growth is evidenced, among other indicators, by the increase in the number of researchers and the increase in scientific production, particularly in terms of publications in indexed journals. The study examined the relationship between the number of researchers in the higher education sector and research and development expenditure in the higher education sector in the economies of Romania and Portugal.

Thus, using two unifactorial regression models, it was found that the models are statistically valid, explaining for Romania and Portugal, respectively, $48.2 \%$ and $89.8 \%$ of the variation in the number of researchers in the higher education sector. The results reflect that, for the period between 2007 and 
2019 , in the higher education sector, a $1 \%$ growth in research and development expenditures leads, on average, to an increase in the number of researchers by $0.18 \%$ in Romania and $1.25 \%$ in Portugal.

Thus, this research can help better decision-making at the level of higher education policies in Romania and Portugal, so it is certain that more financial resources allocated to scientific systems will lead to more researchers and better research outputs, with positive externalities for the economy, and for the society of these two countries.

\section{References}

Antunes, M.G., Mucharreira, P.R., Justino, M.R. and Quirós, J.T., 2018. The Role of TQM, Innovation and Internationalization Strategies on the Financial Sustainability of Higher Education Institutions (HEIS). In Gómez Chova, L., López Martínez, A. and Candel Torres, I. (Eds.), 2018. ICERI 2018 Proceedings - Meeting the Challenges of 21st Century Learning. Seville, Spain: IATED Academy, pp.9778-9787.

Breusch, T.S. and Pagan, A.R., 1979. A Simple Test for Heteroskedasticity and Random Coefficient Variation. Econometrica. 47(5), pp.1287-1294.

Cabrito, B.G., Cerdeira, L., Machado, M.L., Patrocínio, T. and Mucharreira, P.R., 2019. Higher Education in Portugal between 1995-2015 and possible futures, INTED 2019 Proceedings - Exploring New Frontiers in Education. Valencia: IATED Academy, pp.9906-9911.

Cerdeira, L., Cabrito, B.G. and Mucharreira, P.R., 2019. O Crescimento do Ensino Superior no Portugal Democrático: Evolução da Pós-Graduação e da Produção Científica.” [The Growth of Higher Education in Democratic Portugal: Evolution of Graduate Studies and Scientific Production]. Eccos - Revista Científica, 51, pp.1-24.

Cerdeira, L., Cabrito, B.G. and Mucharreira, P.R., 2020. Portuguese scientific system growth and public funding of higher education. In Gómez Chova, L., López Martínez, A., \& Candel Torres, I. (Eds.) (2020). ICERI 2020 Proceedings - Transforming Education, Transforming Lives. Seville, Spain: IATED Academy, pp.8546-8552.

Chebeň, J., Lančarič, D., Munk, M. and Obdržálek, P., 2020. Determinants of Economic Sustainability in Higher Education Institutions. Amfiteatru Economic, 22(54), pp.462-479.

Durbin, J. and Watson, G.S., 1950. Testing for Serial Correlation in Least Squares Regression, I. Biometrika, 37(3-4), pp.409-428.

Imbrișcă, C.I. and Toma, S.G., 2020. Social Responsibility, a Key Dimension in Developing a Sustainable Higher Education Institution: The Case of Students' Motivation. Amfiteatru Economic, 22(54), pp.447-461.

Johnston, R., 2014. Linear Regression Model. In: A.C. Michalos, ed. Encyclopedia of Quality of Life and Well-Being Research. [online] Dordrecht: Springer Netherlands.pp.3621-3627.

Jula, N. and Jula, D., 2010. Modelare economica: modele econometrice si de optimizare. Bucharest: Mustang.

Koenker, R., 1981. A note on studentizing a test for heteroscedasticity. Journal of Econometrics, 17(1), pp.107-112.

Mucharreira, P.R., Cabrito, B.G. and Capucha. L., 2019a. Net Costs of Class-Size Reduction: the Portuguese Case. Cadernos de Pesquisa, 49(172), pp.164-181.

Mucharreira, P.R., Cabrito, B.G. and Capucha. L., 2019b. Impactos Financeiros de uma Política de Redução do Número de Alunos por Turma: o Caso Português. [Financial Impacts of a Policy to Reduce the Number of Students per Class: the Portuguese Case]. Educação, (UFSM) 44(1), pp.120.

Romanian National Institute of Statistics, 2021. Research \& Development statistical publication. [online] Available at: $<$ https://insse.ro/cms/ro/content/activitatea-de-cercetare-dezvoltare-cd-rom$2>$ [Accessed 1 April 2021].

SCImago Institutions Rankings, 2021. SCImago Journal \& Country Rank portal. [online] Available at: $<$ https://www.scimagojr.com/countryrank.php> [Accessed 1 April 2021]. 


BASIQ BASIQ INTERNATIONAL CONFERENCE

Sokolov-Mladenović, S., Cvetanović, S. and Mladenović, I., 2016. R\&D expenditure and economic growth: EU28 evidence for the period 2002-2012. Economic Research-Ekonomska Istraživanja, 29(1), pp.1005-1020.

Statistical Office of the European Communities, 2021. Eurostat Dissemination Database, [online] Available at: $<$ https://ec.europa.eu/eurostat $>$ [Accessed 1 April 2021].

World Bank, 2021. World Development Indicators Database, [online] Available at: $<$ https://data.worldbank.org/indicator/IP.JRN.ARTC.SC $>$ [Accessed 1 April 2021]. 